\title{
Stress and strain analysis using Autodesk Inventor software in soil-cement brick
}

\author{
Análise de tensões e deformações no tijolo solo-cimento utilizando o software Autodesk Inventor \\ Análisis de tensiones y deformaciones mediante el software Autodesk Inventor en ladrillos de suelo-
}

cemento

Received: 10/19/2021 | Reviewed: 10/27/2021 | Accept: 11/03/2021| Published: 11/06/2021

\author{
Ana Carolina Cavalcante de Sousa \\ ORCID: https://orcid.org/0000-0001-7927-3308 \\ Universidade Federal Rural do Rio de Janeiro, Brazil \\ E-mail: carolinacsousa122@gmail.com \\ Fernanda Souza Oliveira \\ ORCID: https://orcid.org/0000-0003-2533-2258 \\ Universidade Federal Rural do Rio de Janeiro, Brazil \\ E-mail: szo.fernanda@gmail.com \\ Simone Pereira Taguchi Borges \\ ORCID: https://orcid.org/0000-0002-7192-0950 \\ Universidade Federal Rural do Rio de Janeiro, Brazil \\ E-mail: simoneptb@hotmail.com.br
}

\begin{abstract}
The computational analysis of materials is fundamental for a better understanding of their physical and mechanical properties, achieving more results in a shorter time. It is a cheaper, non-destructive, practical way, and easily adaptable to various types of models and physical influences. This study has the objective of ascertaining the stress and strain analysis in soil-cement brick through the Autodesk Inventor Professional software, which uses the finite element method. Three models of brick were made: two holes, monoblock, and groove, which are the most commonly used shapes. To the two holes model, the maximum first principal stress observed was $1.464 \times 10^{-1} \mathrm{MPa}$ and the third principal stress was $5.4 \times 10^{-3} \mathrm{MPa}$, presenting an insignificant strain of $1.037 \times 10^{-3} \mathrm{~mm}$. In the monoblock model, the maximum first principal stress was $4.606 \times 10^{-1} \mathrm{MPa}$, and the third principal stress was $1.19 \times 10^{-2} \mathrm{MPa}$, presenting a strain of $1.611 \times 10^{-3} \mathrm{~mm}$. The groove model presented the maximum first principal stress at $3.263 \times 10^{-1} \mathrm{MPa}$ and for the third principal stress was $9.1 \times 10^{-3} \mathrm{MPa}$, respectively, presenting a strain of $3.344 \times 10^{-3} \mathrm{~mm}$. It can also be observed that the models have stress concentrating regions in the sharp edges and notches of the part. Among the three models studied, the one that presented the most favorable stress-strain conditions was the two-hole model. Since it has a larger contact area, the load applied to it was better distributed, presenting higher resistance than the other models with a smaller contact area.
\end{abstract}

Keywords: Autodesk Inventor; Soil-cement brick; Stress and strain analysis.

\section{Resumo}

A análise computacional dos materiais é fundamental para uma melhor compreensão de suas propriedades físicas e mecânicas, obtendo mais resultados em menos tempo. É uma forma mais barata, não destrutiva, prática e facilmente adaptável a vários tipos de modelos e influências físicas. Este estudo tem como objetivo determinar a análise de tensão e deformação em tijolos solo-cimento através do software Autodesk Inventor Professional, utilizando o método dos elementos finitos. Foram feitos três modelos de tijolo: dois furos, monobloco e canaleta, que são as formas mais comumente utilizadas. Para o modelo de dois furos, a primeira tensão principal máxima observada foi $1,464 \times 10^{-1} \mathrm{MPa}$ e a terceira tensão principal foi $5,4 \times 10^{-3} \mathrm{MPa}$, apresentando uma deformação insignificante de $1,037 \times 10^{-3} \mathrm{~mm}$. Para o modelo monobloco, a primeira tensão principal máxima foi de 4,606 $10^{-1} \mathrm{MPa}$, e a terceira tensão principal foi de $1,19 \times 10^{-2} \mathrm{MPa}$, apresentando uma deformação de $1,611 \times 10^{-3} \mathrm{~mm}$. O modelo canaleta apresentou a primeira tensão principal máxima de $3,263 \times 10^{-1} \mathrm{MPa}$ e para a terceira tensão principal foi $9,1 \times 10^{-3} \mathrm{MPa}$, respectivamente, apresentando uma deformação de $3,344 \times 10^{-3} \mathrm{~mm}$. Também pode ser observado que os modelos têm regiões de concentração de tensão nas arestas vivas e nos entalhes da peça. Dentre os três modelos, o que apresentou melhores condições de tensãodeformação foi o modelo de dois furos. Como tem uma área de contato maior, a carga aplicada a ele foi melhor distribuída, apresentando maior resistência do que os outros modelos com uma área de contato menor.

Palavras-chave: Autodesk Inventor; Tijolo de solo-cimento; Análise de tensão e deformação.

\section{Resumen}

El análisis computacional de materiales es fundamental para comprender mejor sus propiedades físicas y mecánicas, consiguiendo más resultados en menos tiempo. Es una forma más barata, no destructiva, práctica y fácilmente adaptable a varios tipos de modelos e influencias físicas. Este estudio tiene como objetivo conocer el análisis de tensiones y 
deformaciones en ladrillos suelo-cemento mediante el software Autodesk Inventor Professional, que utiliza el método de elementos finitos. Se realizaron tres modelos de ladrillo: dos agujeros, monobloque y ranura, que son las formas más utilizadas. En el modelo de dos agujeros, la primera tensión principal máxima observada fue $1.464 \times 10^{-1} \mathrm{MPa}$ y la tercera tensión principal fue $5.4 \times 10^{-3} \mathrm{MPa}$, presentando una deformación insignificante de $1,037 \times 10^{-3} \mathrm{~mm}$. Para el modelo monobloque, la primera tensión principal máxima fue de $4.606 \times 10^{-1} \mathrm{MPa}$, y la tercera tensión principal fue $1.19 \times 10^{-2}$ $\mathrm{MPa}$, presentando una deformación de $1.611 \times 10^{-3} \mathrm{~mm}$. El modelo de ranura presentó la primera tensión principal máxima a $3.263 \times 10^{-1} \mathrm{MPa}$ y para la tercera tensión principal fue $9.1 \times 10^{-3} \mathrm{MPa}$, respectivamente, presentando una deformación de $3.344 \times 10^{-3} \mathrm{~mm}$. También se puede observar que los modelos presentan regiones de concentración de tensiones en los bordes afilados y las muescas de la pieza. Entre los tres modelos estudiados, el que presentó las condiciones de tensión-deformación más favorables fue el modelo de dos agujeros. Al tener una mayor área de contacto, la carga aplicada en él se distribuyó mejor, presentando mayor resistencia que los otros modelos con menor área de contacto.

Palabras clave: Autodesk Inventor; Ladrillo de suelo-cemento; Análisis de tensiones y deformaciones.

\section{Introduction}

Soil-cement brick is a more sustainable alternative than the common brick. It consists of soil, cement, and water, without the burning process, in which large quantities of wood or fuel oil are consumed (Ferraz \& Segantini, 2004), so there are no cutting trees for burning and emission of toxic gases into the atmosphere (Valadão, et al., 2017).

Its structure provides a fitting system, which greatly reduces the use of mortar and reduces the construction time (Jordan \& Freitas, 2018), and its two internal holes make it possible to embed the hydraulic and electric networks, avoiding future breaks in the construction site (Motta, 2014), reducing costs and solid waste disposal.

Besides the ecological advantages, it also presents economic attractiveness since there is a reduction in water and energy consumption (Motta, 2014), which makes it a more accessible material. Thus, it is an alternative to supply a housing shortage (Motta, 2014), since the demand for housing is a frequent problem in developing countries due to the high cost of production (Milani, 2005).

Autodesk Inventor has many applications and is widely used for stress analysis in industrial areas, and for project design, such as beam bracing (Prates, 2020), vehicle chassis (Santos \& Queiroz, 2018), steering wheels (Souto, 2020), and bearings (Bento, 2018).

The finite element method is an approximate numerical method widely applied in engineering, which consists of dividing a continuous domain into small elements that have finite dimensions, "finite elements" (De Souza, 2003; Melo, et al, 2017; Bento \& Ferrus Filho, 2018), while maintaining the properties of the original domain (Lotti, 2006). This makes complex problems simpler and enables more accurate results. The Inventor software uses this method through the application of meshes in the model, either bidimensional or three-dimensional, so it can be used to perform stress and strain analysis of soil-cement brick.

\section{Methodology}

The method applied in the work was scientific research of the experimental type (Cervo, et al., 2007), whose central problem was to identify the use of simulation as an alternative to identify the stresses and strains in various models of soil-cement brick. The hypotheses studied were to use the experimental reference parameters and to assign conditions of use of the brick as a one-story building wall.

Autodesk Inventor has a database with the properties of several materials and appearance suggestions that can be assigned to the model. As ceramic materials present only the silicon nitride and concrete in the database. The dimensions adopted for the bricks models were those supplied by the Verde Equipamentos company (Table 1). Thus, the physical and mechanical properties of soil-cement brick had to be added to the software, considering a survey in the literature for approximate compositions of $10-15 \%$ of cement in brick, as shown in Table 2. For the soil-cement brick modeling, and the performance of 
the stress analysis, it was used Autodesk Inventor Professional software. Figure 1 shows the two-holes model, an example of a hollow brick.

Table 1: Bricks models dimensions.

\begin{tabular}{|c|c|c|c|}
\hline $\begin{array}{l}\text { Dimensions/Models of } \\
\text { soil-cement bricks }\end{array}$ & $\begin{array}{c}\text { Soil-cement brick with two } \\
\text { holes }(\mathrm{mm})\end{array}$ & $\begin{array}{l}\text { Soil-cement monoblock } \\
\qquad(\mathrm{mm})\end{array}$ & $\begin{array}{c}\text { Soil-cement groove brick } \\
(\mathrm{mm})\end{array}$ \\
\hline Width & 125 & 62.5 & 125 \\
\hline Length & 250 & 125 & 250 \\
\hline Height & 65 & 32.5 & 65 \\
\hline $\begin{array}{l}\text { Distance between the } \\
\text { centers of the holes }\end{array}$ & 125 & 62.5 & 125 \\
\hline $\begin{array}{c}\text { Height of the upper bounce } \\
\text { of the hole(s) }\end{array}$ & 7 & 7 & 7 \\
\hline Lower notch of the holes & 9 & - & 9 \\
\hline Notch on center (base) & 2 & - & 2 \\
\hline $\begin{array}{l}\text { Semi-circular format with a } \\
\text { length }\end{array}$ & 65 & - & 65 \\
\hline Gap (base) & - & - & 66 \\
\hline Gap (top) & - & - & 85 \\
\hline Diameter of the holes (mm) & 59 & 59 & 59 \\
\hline $\begin{array}{l}\text { The outer diameter of the } \\
\text { bounces }(\mathrm{mm})\end{array}$ & 81 & 81 & 81 \\
\hline The inner diameter $(\mathrm{mm})$ & 59 & 59 & 59 \\
\hline $\begin{array}{l}\text { The edge diameter of the } \\
\text { upper bevels }(\mathrm{mm})\end{array}$ & 74 & 74 & 74 \\
\hline $\begin{array}{l}\text { The lower outer diameter } \\
\text { (mm) }\end{array}$ & 84 & 84 & 84 \\
\hline $\begin{array}{l}\text { The lower inner diameter } \\
\qquad(\mathrm{mm})\end{array}$ & 76 & 76 & 76 \\
\hline
\end{tabular}


Table 2: Physical and mechanical properties of soil-cement brick.

\begin{tabular}{cc}
\hline Properties of soil-cement brick & \\
\hline$*$ Density $\left(\mathrm{Kg} / \mathrm{m}^{3}\right)$ & 2.764 \\
$* *$ Yield strength $(\mathrm{MPa})$ & 0.46 \\
$* *$ Ultimate tensile strength $(\mathrm{MPa})$ & 0.46 \\
$* *$ Young's modulus $(\mathrm{GPa})$ & 5 \\
$* * *$ Poisson's ratio & 0.19 \\
Shear modulus $(\mathrm{GPa})$ & 2.10 \\
\hline
\end{tabular}

Source:*(Jesus Junior, 2018); **(Reddy \& Gupta, 2005); ***(Mosalam, et al., 2009).

Figure 1: Soil-cement brick modeled in Autodesk Inventor 2018. (a) model simulating material color and superior details; (b) model with defined mesh parameter.

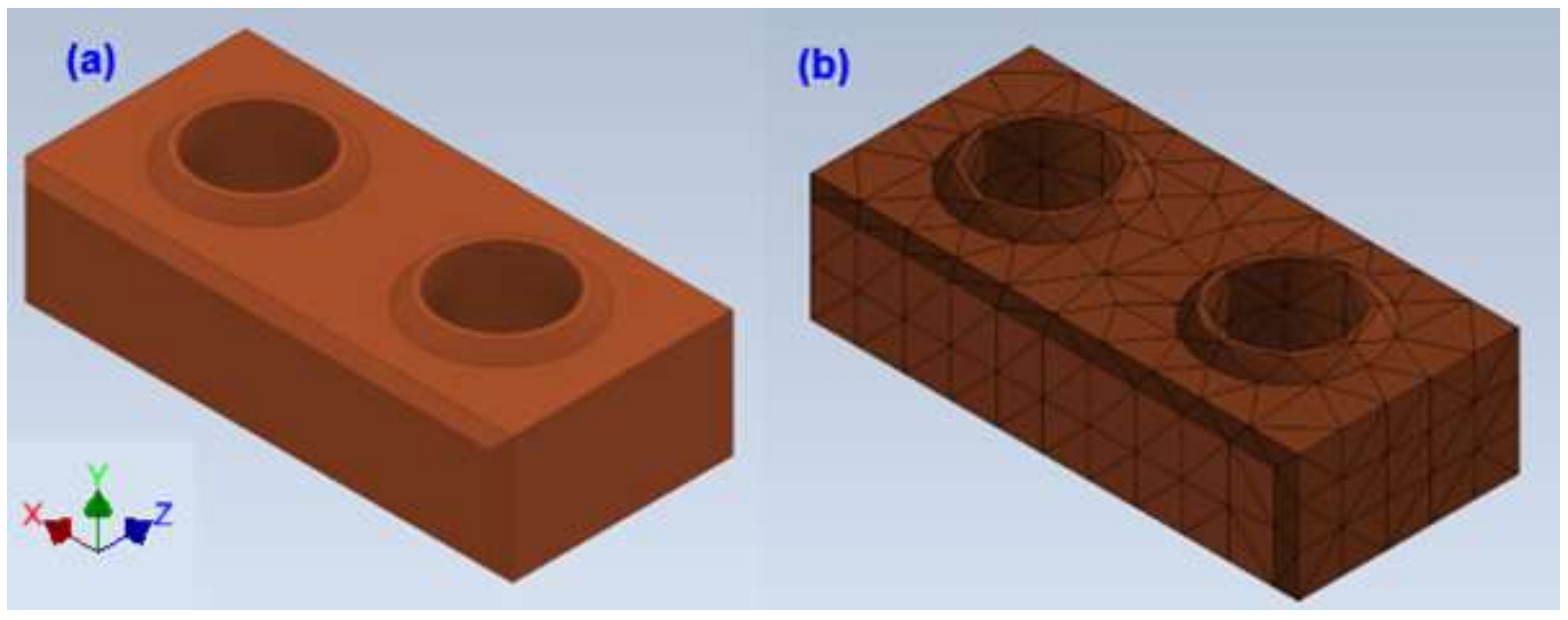

Source: Authors.

In Figure 1 it is possible to see the soil-cement brick model simulated in the Autodesk Inventor program, which, due to the program's functions, is very similar aesthetically to the real model. On the right of the image is the model in the finite element method standards with the mesh parameter.

Autodesk Inventor uses the finite element method to calculate the distribution of forces applied to the model, which consists of the formation of several polygons that restrict the area to be studied, reducing error and bringing the calculations closer to actual results. These formed polygons are called "mesh parameters", which define the average and minimum size of the elements, leveling factor, and maximum turning angle. The parameters used in the mesh configuration were 0.099 for the average size of the elements, 0.200 for the minimum size of the elements, 1.500 for the leveling factor, 60.00 for the maximum turning angle, and the creation of curved mesh elements.

The soil-cement brick with 2 holes is normally used in walls, with the purpose of sealing, that is, without a load-bearing function. In this way, the load that usually bears is only the weight of the bricks stacked on it. For the dimensioning of the force applied to the brick, the load estimated in the stacking $\left(C_{e m p}\right)$ was used considering the first brick of a standard construction row bearing the weight of the other bricks above it and is indicated in Equation A. The side of force application was the loading surface shown in Figure 2 and left the side and bottom surfaces fixed, as shown in Figure 3. 


$$
C_{e m p}=\frac{H}{h}(m \cdot g)
$$

$C_{e m p}=$ Estimated load on stacking $(\mathrm{N}) ; H=$ Height of a wall $(\mathrm{m}) ; h=$ Thickness in the brick $(\mathrm{m}) ; m=$ Mass of the brick $(\mathrm{Kg}) ; g=$ Gravitational acceleration $\left(\mathrm{m} / \mathrm{s}^{2}\right)$.

Figure 2: Selected side for force application (a) two holes model; (b) monoblock model; (c) groove model.

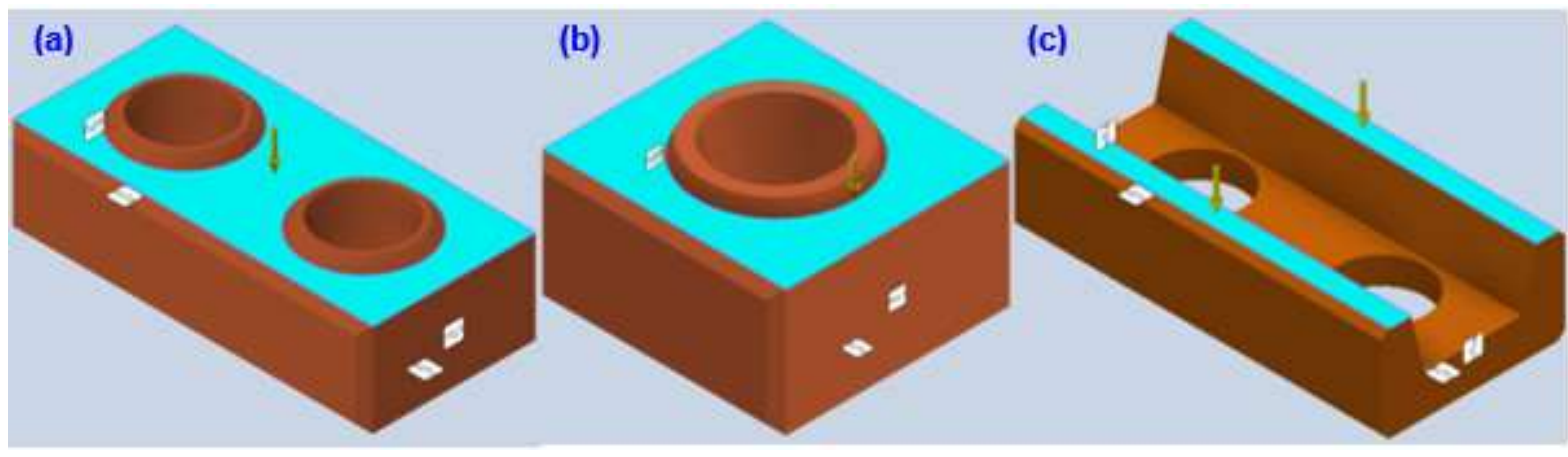

Source: Authors.

Figure 3: Fixed sides. (a) top view; (b) bottom view.

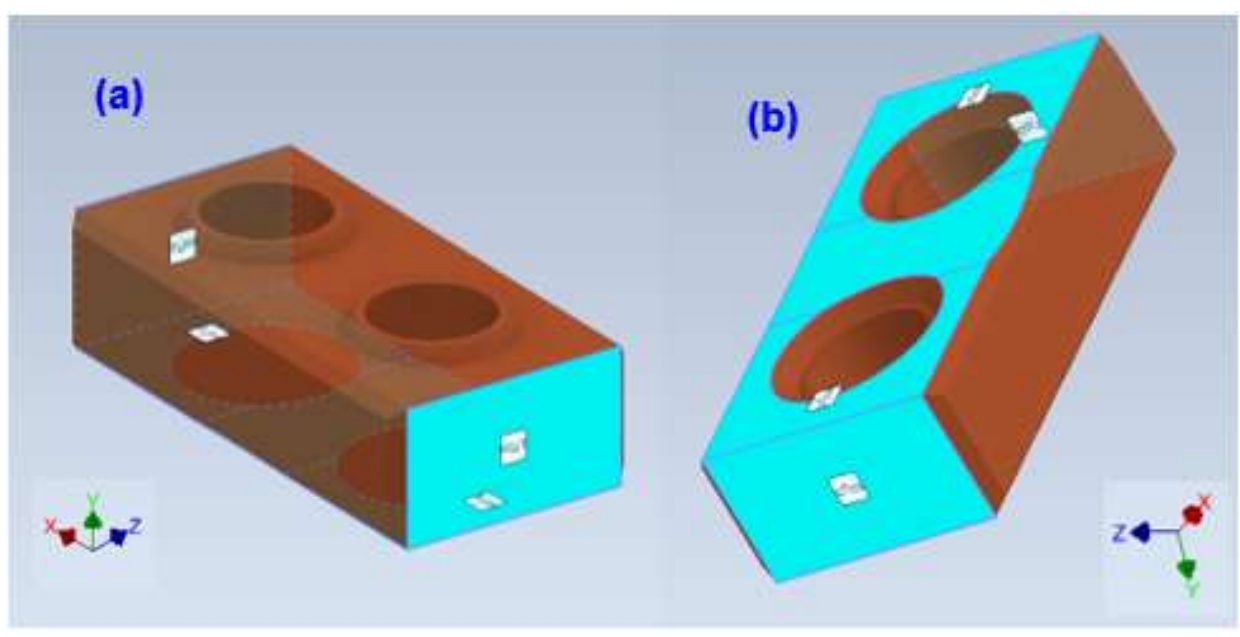

Source: Authors.

In Figure 3 it is observed that the fixed faces of the brick are the sides and bottom, so the software determines that there are contacts in these areas. Thus, these regions will present a higher compressive load in the stress analysis.

The soil-cement brick is used in the production of non-bearing insulating walls, and the two-hole and monoblock models are used in stacking in an intercalated manner, which stabilizes the structure, avoiding the action of high shear stresses that could affect the integrity of the wall. And the groove model is used for the passage of ducts and pipes, avoiding unnecessary breakage of parts; this can also be used in the making of beams.

According to Hibbeler (2015), the principal stresses represent the maximum normal stress and the minimum normal stress at the point, and Equation B is used to determine it. This result gives the maximum or minimum normal stress in the plane acting at a point, $\sigma_{1} \geq \sigma_{2}$ depending on the chosen signal. This set of particular values is called principal stress in the plane, and the corresponding planes that they act are called principal stress planes, as shown in Figure 4.

$$
\sigma_{1,2}=\frac{\sigma_{x}+\sigma_{y}}{2} \pm \sqrt{\left(\frac{\sigma_{x}+\sigma_{y}}{2}\right)+\tau_{x y}^{2}}
$$


Figure 4: Representation of the plane stress state.

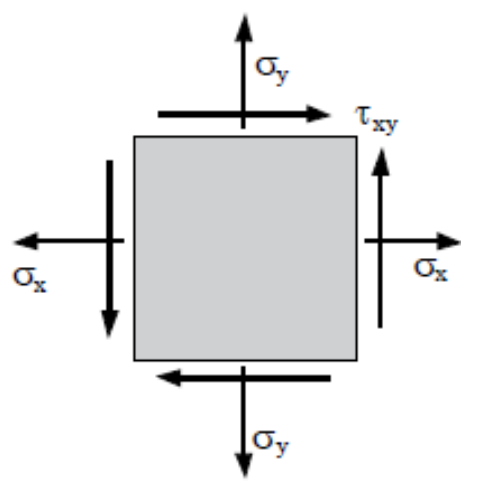

Source: Hibbeler (2015).

Figure 4 illustrates the stress plane, where the stresses applied perpendicular to the surface represent the tensile stresses in the material, and the stresses parallel to the surface represent the shear stresses in the material. These stresses occur in the material when a compressive stress is applied, which can be observed in the first and third principal stresses.

\section{Results and Discussion}

The value obtained using Equation A, considering a $3 \mathrm{~m}$ height wall, was $1663.15 \mathrm{~N}$. It is referred to the estimated stacking load was assigned to the force parameter applied to the model on its upper side.

The first principal stress (Figure 5 (a) for the two holes, (b) for the monoblock and (c) for groove brick) refers to the value of the stress that is normal to the plane where the shear stress is zero and helps to understand the yield strength, represented by the red color in the spectrum of the model. As for the third principal stress represented in Figure 6 (a) and (b) for the two holes, (c) and (d) for the monoblock, (e) and (f) for groove brick, it acts in the opposite way to the normal plane direction. It represents the maximum compressive stress, composing the lower limit of the color spectrum, in blue.

According to Callister Jr and Rethwisch (2012) stress amplification is not restricted only to microscopic flaws; it can also occur in macroscopic internal discontinuities, sharp edges, and notches. Thus it can be analyzed that reacting to the load applied, the brick has a concentration of stress in the edges of the side surfaces, in the notches on the bottom, and the bumps on top of the holes.

For the two holes brick was verified the strain of only $1.037 \times 10^{-3} \mathrm{~mm}$ (Figure 7 (a)) characteristic of ceramic materials, which are relatively rigid and resistant, present fragile behavior because ceramics fail after a strain of only approximately $0.1 \%$ (Callister Jr \& Rethwisch, 2012). The percentage distant from the strain of $1.105 \times 10^{-3} \mathrm{~mm}$ given by the software. For the other two models the strain was also small (Figure 7 (b) and (c)), being in line with the characteristics of the material. Linear distributed loads produce a resulting force that passes through the area centroid (Buffoni, 2017). Thus a concentrated strain was observed in the central region of the brick, due to its load distribution. The results of the stress analysis, first and third maximum and minimum principal stress, and strain, obtained through the Inventor software can be seen in Table 3. 
Figure 5: First Principal stress: (a) two holes model first principal stress; (b) monoblock model first principal stress; (c) groove brick first principal stress.

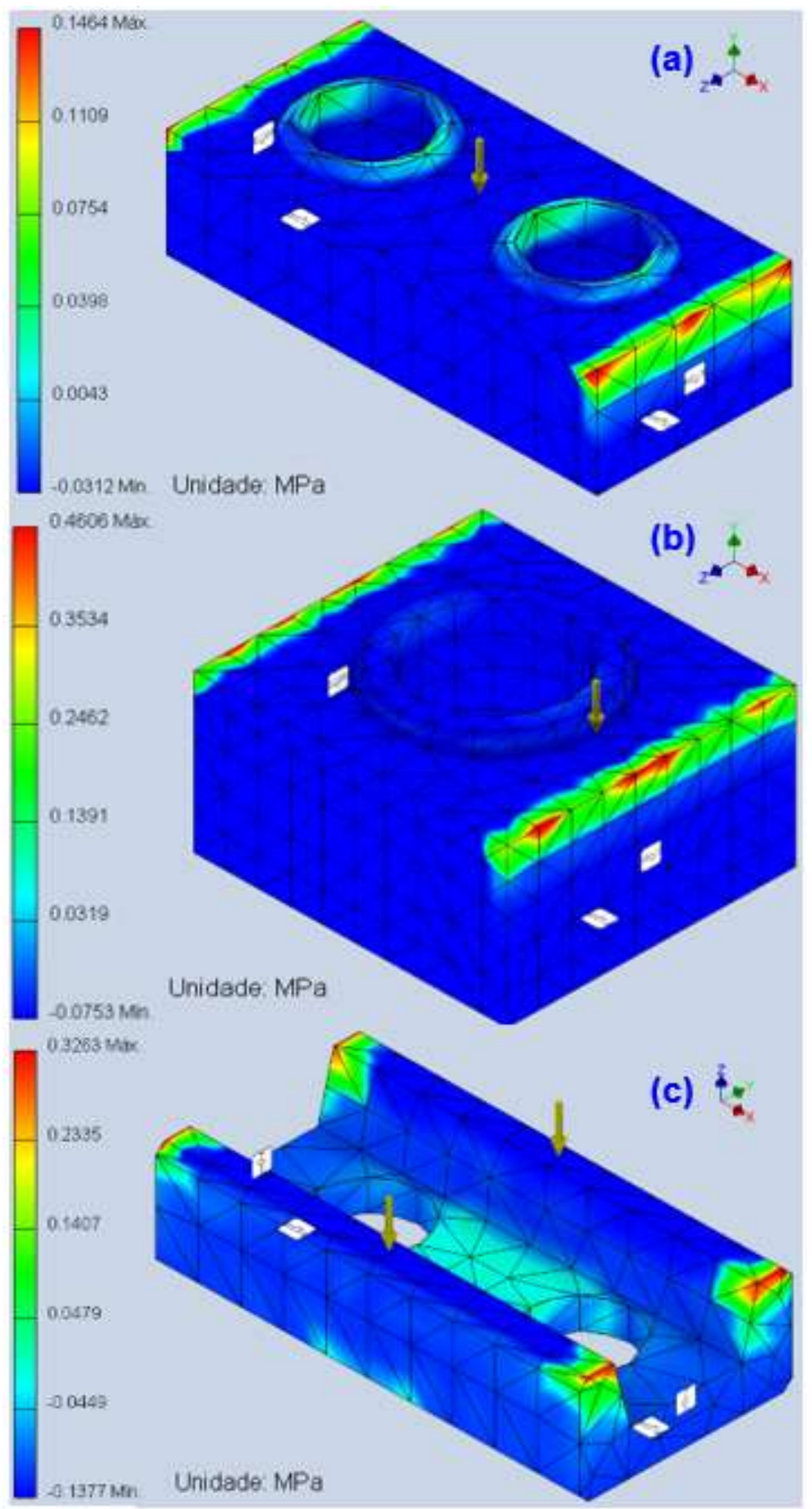

Source: Authors.

Figure 5 illustrates the first principal stress in the models. In all of them, the red areas that present the greatest stress are the edges of the upper faces that are in contact with the fixed regions. The maximum values obtained for the three models were low (from $0.1-0.4 \mathrm{MPa}$ ) and do not compromise the integrity of the bricks. The edges that are exposed to the inside or outside of the building do not present a stress concentration, only the parts that are in contact with other bricks. This is positive to preserve the external or internal appearance of the construction, not requiring a plaster to cover possible edge defects. 
Figure 6: Third principal stress: (a) two holes model top view; (b) two holes model bottom view; (c) monoblock top view; (d) monoblock bottom view; (e) groove brick top view; (f) groove brick top view.

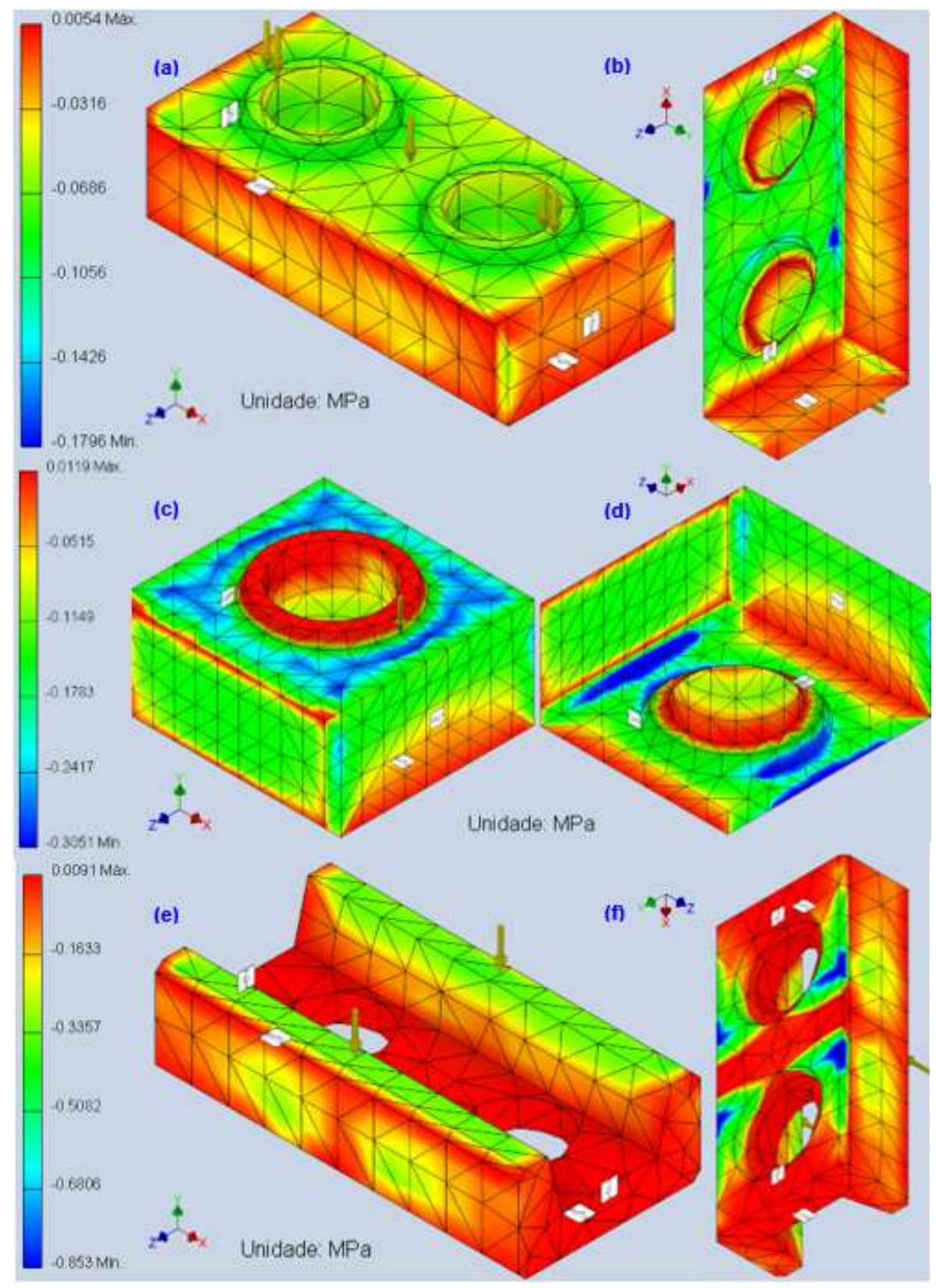

Source: Authors.

In Figure 6, it can be observed the action of the third principal stress in the models, in all of them the areas in red present the maximum compressive values. In the two holes model the highest compression values are found on the sides, in the monoblock they are concentrated in the hole, while in the groove model they are distributed over almost all its surface. 
Figure 7: Strain: (a) two holes strain; (b) monoblock strain; (c) groove brick strain.

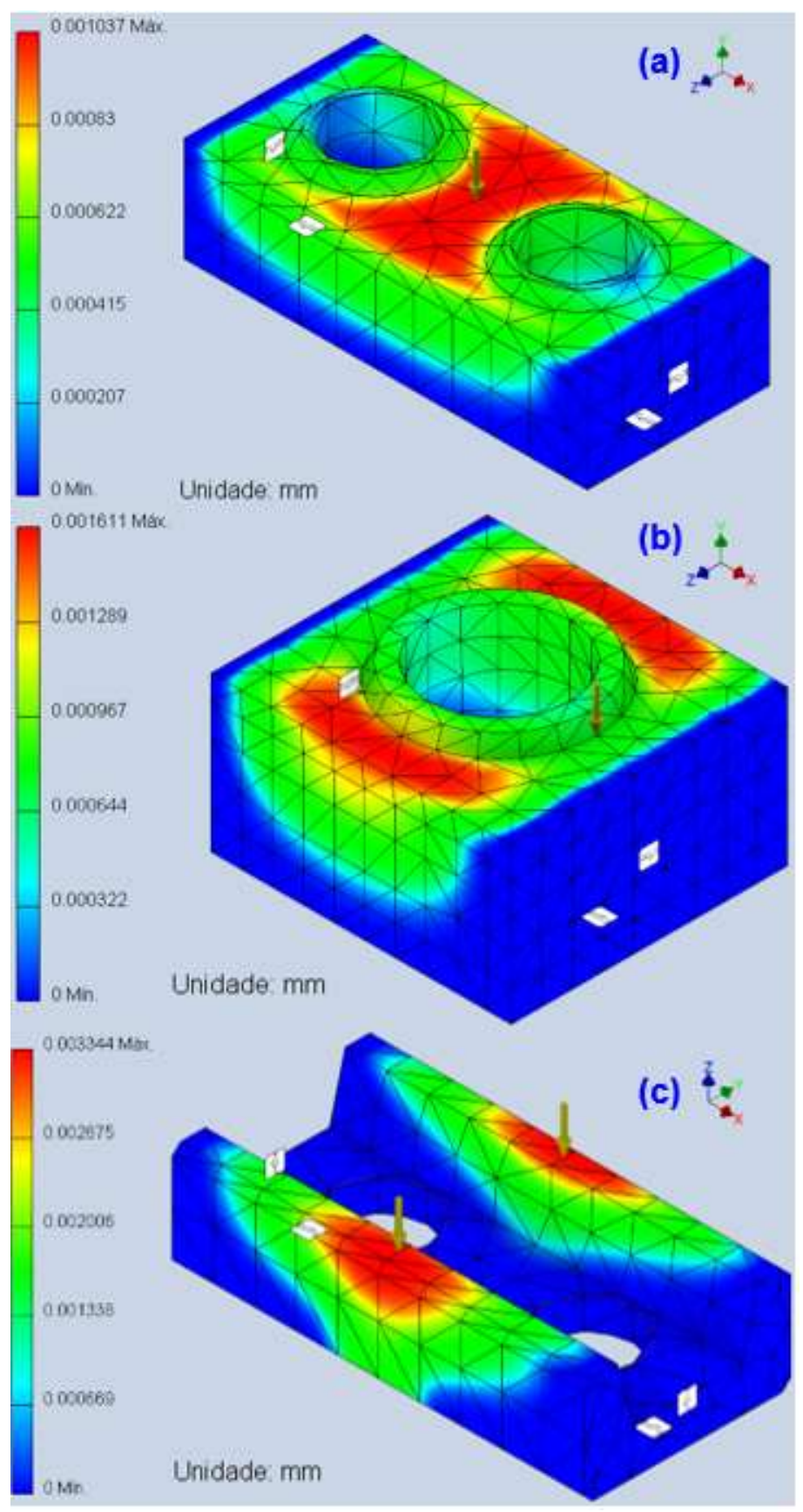

Source: Authors.

Figure 7 gives information about the strain suffered by the model, where the red region is associated with the largest strain suffered. The scale on the left shows the maximum values of strain, which in all models were very small, demonstrating the possible integrity of the models. The deformation in all models tends to be concentrated in the center of the brick. 
Table 3: Stress and strain analysis of the bricks.

\begin{tabular}{cccc}
\hline & $\begin{array}{c}\text { Soil-cement brick with } \\
\text { two holes }\end{array}$ & $\begin{array}{c}\text { Soil-cement } \\
\text { monoblock }\end{array}$ & $\begin{array}{c}\text { Soil-cement groove } \\
\text { brick }\end{array}$ \\
\hline First principal stress, max (MPa) & $1.464 \times 10^{-1}$ & $4.606 \times 10^{-1}$ & $3.263 \times 10^{-1}$ \\
First principal stress, min (MPa) & $-3.12 \times 10^{-2}$ & $-7.53 \times 10^{-2}$ & $-1.377 \times 10^{-1}$ \\
Third principal stress, max (MPa) & $5.4 \times 10^{-3}$ & $1.19 \times 10^{-2}$ & $9.1 \times 10^{-3}$ \\
Third principal stress, min (MPa) & $-1.796 \times 10^{-1}$ & $-3.051 \times 10^{-1}$ & $-8.53 \times 10^{-1}$ \\
Strain (mm) & $1.037 \times 10^{-3}$ & $1.611 \times 10^{-3}$ & $3.344 \times 10^{-3}$ \\
\hline
\end{tabular}

Source: Generated from Autodesk Inventor by the authors.

\section{Conclusion}

We can conclude that the soil-cement brick has many applications and is a commercial product of notable importance, thus, the studies that seek to improve its properties are important. And with the use of Autodesk Inventor, which is a very convenient software for computational analysis of the physical and mechanical effects of soil-cement brick. Since it is a more practical method of studies and without the need for large investments, it is possible to analyze the behavior of the forces acting on the model, adapting the parameters for the most diverse purposes.

Based on the results obtained, the models presented are more practical and ecological to use, and can be used in civil construction for making non-bearing insulation walls, with the facility of having a specific model for the arrangement of ducts and pipes, and also as a mold for beams.

Considering the graphic results of the stress, it can be concluded that the edges whose angle is near or equal to $90^{\circ}$, have a higher concentration of stress, becoming a region most susceptible to fracture. The results obtained for the model studied, being a fragile material, resulted in an insignificant strain between $1.037 \times 10^{-3} \mathrm{~mm}$ and $3.344 \times 10^{-3} \mathrm{~mm}$. Such results demonstrate that the soil-cement brick in its different presentations can be used as a non-bearing sealing element, respecting the mandatory criteria of the standard.

For future work it is suggested to develop the experimental part of the models to compare the results obtained experimentally with those obtained through simulations. Another suggestion is to use the program for modeling other sizes and shapes of soil-cement bricks to improve understanding of the stresses in various models.

\section{Acknowledgments}

Our special thanks to Proext UFRRJ and CNPq for the scholarships, and Verde Equipamentos for the model designs and support.

\section{References}

Bento, R. T. \& Ferrus Filho, A. (2018). $23^{\circ}$ Congresso Brasileiro de Engenharia e Ciência dos Materiais. Análise do comportamento estático de mancais hidrodinâmicos pelo método de elementos finitos. Foz do Iguaçu, PR, Brasil.

Buffoni, S. S. (2017). Apostila de resistência dos materiais. Volta Redonda, RJ, Brasil: Escola de engenharia industrial metalúrgica de Volta Redonda da UFF. Callister Jr., W. D. \& Rethwisch, D. G. (2012). Ciência e Engenharia dos Materiais: Uma Introdução. LTC.

Cervo, A. L. (2007). Metodologia científica. Pearson Prentice Hall.

De Souza, R. M. (2003). O método dos elementos finitos aplicado ao problema de condução de calor. Belém, Pará, Brasil: Universidade Federal do Pará. 
Ferraz, A. L., \& Segantini, A. A. (2004). Engenharia sustentável: aproveitamento de resíduos de construção na composição de tijolos de solo-cimento. Encontro de Energia no Meio Rural, 5.

Hibbeler, R. C. (2015). Resistência dos materiais. Pearson Prentice Hall.

Jesus Junior, N. P. (2018). Influência da composição na absorção de água de tijolos solo-cimento incorporados com resíduo de rocha ornamental, $36 f$. Trabalho de conclusão de curso. Seropédica, RJ, Brasil: Departamento de engenharia química da Universidade Federal Rural do Rio de Janeiro.

Jordan, A. D., \& Freitas, V. A. (2018). Aplicações do tijolo ecológico na construção civil. Etic-Encontro de Iniciação Científica, 14(14).

Lotti, R. S. (2006). Aplicabilidade científica do método dos elementos finitos. Rev. Dent. Press Ortodon. Ortop. Facial, 11(2), $35-43$.

Melo, I. C., Coutinho, J. R., Filho, F. D., Freitas, D. B., Rocha, B. M., \& Araújo, B. A. (2017). Análise numérica da estrutura do mausoléu Castelo Branco. Revista Tecnologia. Fortaleza, CE, Brasil.

Milani, A. P. (2005). Avaliação físico-mecânica de tijolos de solo-cimento e de solo-cal adicionados de casca de arroz, 113p. Dissertação (mestrado). Campinas, SP, Brasil: Universidade Estadual de Campinas, Faculdade de Engenharia Agrícola.

Mosalam, K., Glascoe, L., \& Bernier, J. (2009). Mechanical Properties of Unreinforced Brick Masonry. Livermore, CA, United States: Lawrence Livermore National Lab. (LLNL).

Motta, J. C. (2014). Tijolo de solo-cimento: análise das características físicas e viabilidade econômica de técnicas construtivas sustentáveis. E-xacta, 7(1), 1326.

Prates, P. R., Navari, J. C., Augustinho, G. C., Júnior, S. A., \& Caminaga, C. (2020). Análise por elementos finitos e validação analítico-numérica do fenômeno da flexão engastada em barras maciças utilizando o software Autodesk Inventor Professional 2021®. V Encontro de Iniciação Científica e Tecnológica (V EnICT). Araraquara, SP, Brasil: Instituto Federal (IF).

Queiroz, E. N., Lopes, A. P., \& Santos, A. A. (2018). Análise de impacto frontal em um chassi space frame do tipo mini baja. Congresso Técnico Científico da Engenharia e da Agronomia. Maceió, AL, Brasil.

Reddy, B. V., \& Gupta, A. (2005). Characteristics of soil-cement blocks using highly sandy soils. Materials and structures, 38(6), 651.

Santos, J. L., Oliveira, P. E., \& Paschoal, A. J. (2019). Projeto e simulação do chassi de um carro fórmula SAE. III Congresso Internacional de Gestão e Tecnologias. Recife, PE, Brasil.

Souto, J. I., \& Santana, R. A. (2020). Análise e otimização de um volante de inércia para aplicação em um sistema mecânico de recuperação de energia cinética (MKERS) em uma motocicleta onroad. V Congresso Nacional de Pesquisa e Ensino em Ciências. Campina Grande, PB, Brasil.

Valadão, I. C., Vilela, F. O., \& Faria, J. (2017). Produção de tijolos ecológicos no UGB. Episteme Transversalis, 6(1). 